\title{
Board Game Violetas: the perspective of professionals addressing violence against women*
}

\author{
Jogo Violetas: a perspectiva dos profissionais que participam do enfrentamento \\ da violência contra a mulher \\ Juego Violetas: la perspectiva de los profesionales que participan del enfrentamiento \\ de la violencia contra la mujer
}

How to cite this article:

Fornari LF, Fonseca RMGS. Board Game Violetas: the perspective of professionals addressing violence against women. Rev Esc Enferm USP. 2021;55:e20200238. doi: https://doi.org/10.1590/1980-220X-REEUSP-2020-0238

D Lucimara Fabiana Fornari ${ }^{1}$

Rosa Maria Godoy Serpa da Fonseca²

* Extracted from the thesis "Potencialidades e limites do Jogo Violetas para o enfrentamento da violência de gênero" (Potentialities and limits of the board game Violetas to address gender violence), Universidade de São Paulo, Escola de Enfermagem, 2019.

${ }^{1}$ Universidade de São Paulo, Escola de Enfermagem, Programa de Pós-Graduação em Enfermagem, São Paulo, SP, Brazil.

${ }^{2}$ Universidade de São Paulo, Escola de Enfermagem, Departamento de Enfermagem em Saúde Coletiva, São Paulo, SP, Brazil.

\section{ABSTRACT}

Objective: To analyze the potentialities and limits of the board game Violetas to address violence against women, from the perspective of the professionals who work in assisting the victims. Method: This is an interventional study with a qualitative approach. Thirty professionals from the Casas da Mulher Brasileira (Brazilian Women's Houses) in Brasília, Campo Grande and Curitiba participated. Data collection was carried out during Critical-Emancipatory Workshops. Data were subjected to thematic content analysis with the support of the software webQDA. Results: As potentialities, the professionals mentioned the game design, the collaborative participation, and the ludicity as learning facilitators, stimulating reflections on the visibility of violence, assistance to victimized women, and the articulation of the supportive network services. As limitations of the study, the lack of familiarity with games, the understanding of the rules, and some issues contained in the game were mentioned. Conclusion: The game proved to be a powerful educational strategy for the training and qualification of the professionals involved in the supportive network.

\section{DESCRIPTORS}

Violence Against Women; Games Experimental; Gender and Health; Nursing Care; Education. 


\section{INTRODUCTION}

Violence against women is a prevalent and systematic threat to human rights. Due to its generalized incidence, it can be considered a pandemic, with a serious impact on the areas of health, well-being, education, and economy ${ }^{(1)}$. Given this magnitude, coping with this was considered a priority for sustainable development, since the 2030 Agenda proposes as a fifth objective to achieve gender equality and to empower women and girls, aiming at eliminating all forms of violations in the context of public and private life ${ }^{(2)}$.

Such elimination involves actions to prevent and deal with the problem. A systematic review with meta-analysis, related to the effectiveness of interventions for the prevention of domestic violence in low- and middle-income countries, found the need for informative, educational, and communicative actions as mechanisms to transform traditional gender standards in different sectors of the society, including health, politics, research, religion, and the $\operatorname{media}^{(3)}$.

Therefore, there is a need for training and qualification of professionals involved in assisting women in situations of violence, as they have an important role in identifying and addressing the problem. Studies reveal that the lack of educational strategies in this approach is a problem both in undergraduate education ${ }^{(4)}$ and in continuing education programs $s^{(5)}$. The lack of understanding and the presence of discriminatory attitudes and behaviors are barriers to the support of women, underpinning situations of violence.

In view of the foregoing, a playful educational strategy entitled Violetas: Movies \& Action in addressing violence against women was developed. This is a cooperative board game, which aims to support learning and the exchange of experiences among students and professionals involved in the care of women in situations of violence. Each player takes on the role of a character (educator, legal operator, member of public policies or health professional, and citizen of the women's movement) and everybody plays collectively against the board to prevent violence by answering questions related to scenes of films and through strategic actions for the defense of citizenship ${ }^{(6)}$.

The playability of Violetas was tested through research with 12 specialists and 111 other participants, including undergraduates, professionals, and researchers, in which the rules, mechanics, and design of the game were validated ${ }^{(6)}$. As a continuation, the present study had as objective to know the possibilities of the game for the expansion of the professionals' critical awareness concerning the subject. Therefore, the following guiding question was considered: How can the board game Violetas stimulate the thoughts and reflections of the professionals working with women in situations of violence on ways to face the problem? The objective of this study was to analyze the potentialities and limits of the board game Violetas to address violence against women, from the perspective of the professionals who work in assisting the victims.

\section{METHOD}

\section{Type of Study}

This is an interventional study with a qualitative approach. The approach to and the comprehension of the research object were carried out based on the analytical categories gender, gender violence, and critical-emancipatory education, anchored to historical and dialectical materialism.

\section{LOCAL}

The study had as its research scenario the first three units of the Casa da Mulher Brasileira (Brazilian Women's House) (CMB) operating in the country, located in Brasilia, Campo Grande, and Curitiba. CMB is a public policy, created in 2013, to address violence against women through the integration, expansion, and articulation of the services composing the service network ${ }^{(7)}$.

The selection of these units is justified due to the time of operation at the time of data collection, with an opening date of more than two years. Thus, it was assumed that the work process of professionals in the service sectors was consolidated, based on the services routine and functioning.

\section{Selection Criteria}

All professionals who worked in the CMBs at the time of data collection were invited to participate voluntarily in the study. The invitation was made face-to-face in all service sectors, by the institutions' coordinators themselves. Selection was random, according to the participants' convenience. Only those who showed interest in the game and availability for data collection participated, as this was done during working hours. Professionals who did not attend women in situations of violence and, subsequently, who did not participate in the first session of data collection were excluded.

\section{SAmple Definition}

The number of participants was not pre-defined, as the study aimed to know the singularities and the meanings associated with the phenomenon, expressed through opinions, representations, behaviors, and practices ${ }^{(8)}$.

Thirty professionals who worked at the CMB participated in the study, eight from Brasília, 16 from Campo Grande, and six from Curitiba. The sessions for data collection took place according to the participants' availability, ensuring that a minimum of four and a maximum of 16 professionals from each $\mathrm{CMB}$ unit would participate. This measure was adopted because the game Violetas allows four to eight players per game. Two matches were played with four players in Brasilia, two matches with eight players in Campo Grande and one match with six players in Curitiba.

\section{Data Collection}

Data collection took place from January to March 2018, through a Critical-Emancipatory Workshop (CEW) with two sessions of three hours each, totaling six hours per unit of the CMB. The workshop consists of an investigation and intervention method using collective construction of 
knowledge. It is based on critical-emancipatory education and feminist epistemology, being divided into four moments: warm-up, individual reflection, group reflection, and synthesis $^{(9-10)}$.

The implementation of this data collection technique involved the use of a pre-defined schedule, including guiding questions. In the first session, the participants expressed their expectations and subsequently played a game. In the second session, they expressed their impressions about the participation in the game, with regard to facilities and limits, and the relationship between the game and gender issues, gender violence, and their coping.

The schedule was tested in a pilot workshop with seven professionals enrolled in graduate programs. The sessions took place in an appropriate space and according to the time provided for in the schedule. At the end, the professionals gave their impressions about the experience. The moment was recorded through video and fieldnotes. Following the test analysis, minor changes in the wording and sequence of the questions were made.

The workshops were held at the institutions themselves, as they had appropriate physical space and easy access for the participants during working hours. There was also a previous period of five days of observation in each research scenario, to allow capturing the reality, exploring, and interpreting the empirical material produced in the CEW. Observation also supported the reflection on the professionals' speeches, according to the context in which they were inserted.

\section{Data Analysis and Treatment}

Data consisted of the participants' speeches that were recorded, transcribed in full and analyzed by means of thematic content analysis, which provides for the following steps: pre-analysis, material exploration, treatment of results, interpretation, and inference ${ }^{(11)}$.

The software Web Qualitative Data Analysis (webQDA) was used to support data analysis. It is structured in four systems: Sources, Coding, Questioning, and Management ${ }^{(12)}$. In this study, data were aggregated according to each institution and entered in the software as Internal Sources.

After reading the data in full, the empirical categories were constructed using the Codes Tree. The empirical categories related to the potentialities and limits of the game were defined according to the objective of the study. The third category emerged from the reports that stood out from the previous categories. The first author of this research carried out the codification of the speeches, while the second author carried out the codes validation according to the empirical categories. To settle disagreements, a consensus meeting was held. The participants' characterization was elaborated through the Descriptive Codes.

With regard to the Questioning system, a search was made for the most frequent words expressed by the participants in the CEW, to map the diversity of themes. Four analysis matrices were also proposed that correlated the number of comments per participant with the age group, profession, length experience in the profession and at CMB.
The study used the instrument Consolidated criteria for reporting qualitative research (COREQ) to check all method stages.

\section{EThical Aspects}

The study met all the requirements proposed by Resolution 466, of December 12, 2012, of the National Health Council, which provides for the rules and guidelines of research involving human beings ${ }^{(13)}$. The project was approved by the Research Ethics Committee of the Nursing School of University of São Paulo in 2017, under opinion number 2.026.647. It was also presented to the CMB units, for knowledge and authorization for data collection. The collection was conducted after questions related to the development of the research were clarified and the Free and Informed Consent Form was signed by the participants.

Participation in the study was voluntary and anonymity was ensured with the replacement of the participants' names with the letter "P", followed by Arabic numerals. As most professionals participating in this study are female, in the subsequent sections the female grammatical gender (in the text in Portuguese) will be adopted to refer to the participants' statements.

\section{RESULTS}

Twenty-seven female and three male professionals participated in the study. Most of the participants were in the age group between 30 and 39 years old (13). Regarding the work, 18 participants worked in the psychosocial sector, 19 had more than 10 years of professional practice, and experience at CMB below one year (10) (Figure 1).

The matrices revealed that the number of comments was not related to the age group, with the greatest participation being from social workers and psychologists, as well as from participants with professional experience over 20 years. In Brasilia, there was a greater participation of professionals with two years of experience at CMB; in Campo Grande, less than a year; and, in Curitiba, one year of experience.

The most frequent words pointed out sets related to the game (card, film, laughter, issue, question), the phenomenon (violence, women, gender, health, law), and the professional practice (work, coping, strategy, attention, all) (Figure 2).

The observation period in each research scenario revealed the institutions' uniqueness, inserted in heterogeneous geopolitical spaces. Although the object of work and the infrastructure of the institutions are similar, there were particularities associated with the care of women in situations of violence that were reflected in the participants' statements.

Data analysis led to the emergence of three empirical categories: Potentialities of the board game Violetas to face violence against women; Limits of the board game Violetas to face violence against women; and Reflections stimulated by the board game Violetas for professional practice. 


\section{Length of experience at CMB}

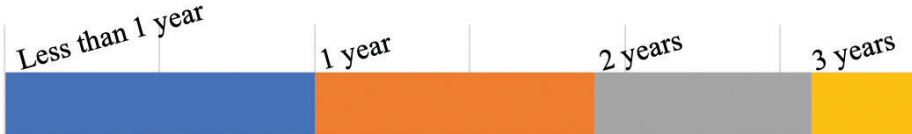

\section{Length of professional experience}

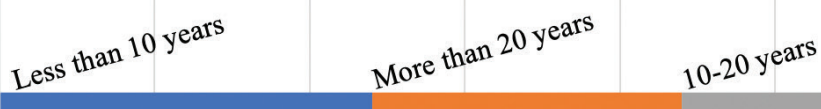

\section{Area of care at CMB}
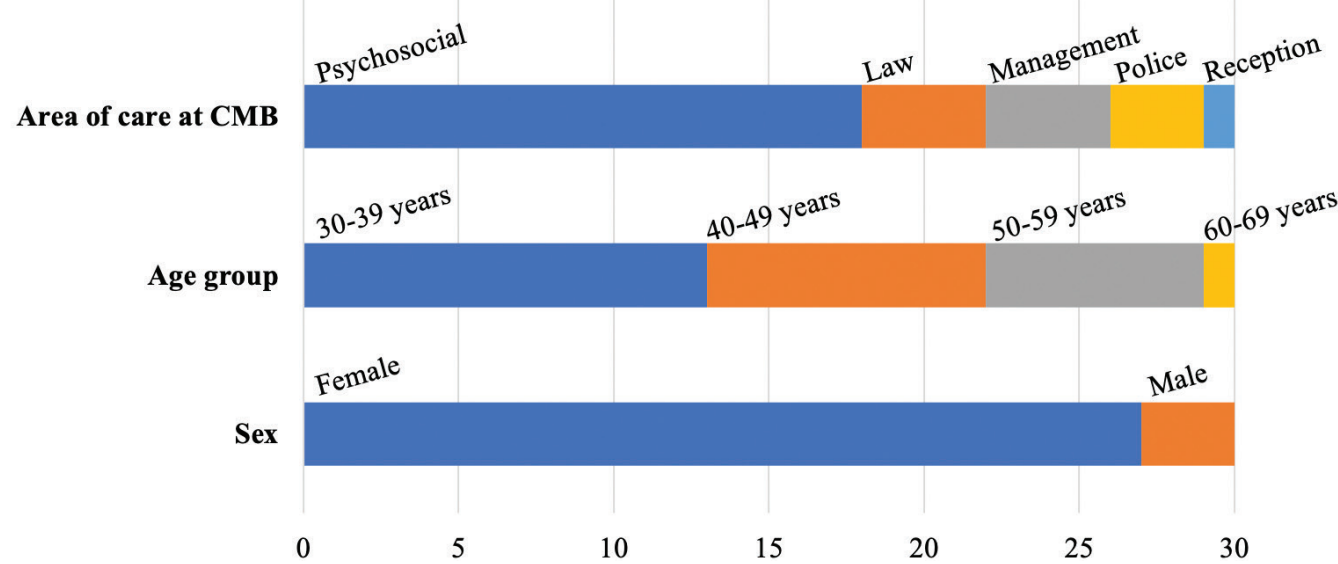

Figure 1 - Characterization of the research participants.

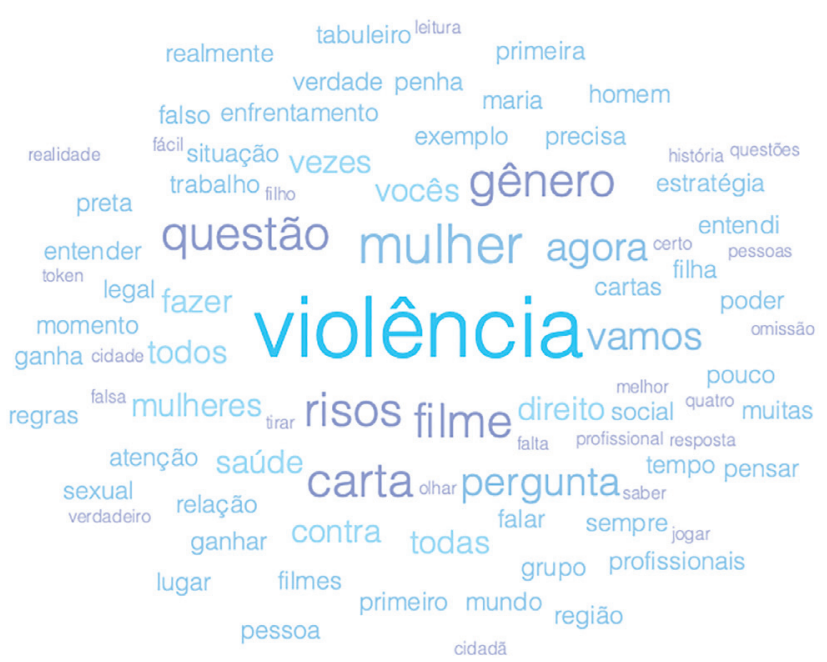

Figure 2 - Most frequent words in data collection using webQDA.

\section{Potentialities of the Board Game Violetas to Face Violence Against Women}

The game design was related to the beauty related to the female universe and to the motivation for joining the game, promoting the participants' attention and curiosity.

The material itself, the design, the colors of the game, instigates the desire to get to know it and play. It is a well-structured game, its colors are beautiful (P9).

The game questions were considered to be similar to case studies. The participants felt provoked to respond assertively and formulated the answers based on the experiences from professional practice.
We professionals have to be very clear about this issue of domestic violence, because we are assisting the victims, we have to have a position, we have to be clear about that. So, it's searching all the time, reading all the time. It is cool for us to exchange these experiences, sometimes, when we read, it is one thing, now when we read and share with others it is something else. (...) so it is in these moments that we really learn and make it real. I think this foundation is fundamental, because a house without a foundation, wind blows once and it falls. We professionals need this very well-founded structure for us not to fall with the first wind, we have to have this foundation, this basis (P2).

According to the participants, knowledge about violence against women can be achieved through interaction and sharing of experiences lived by professionals working in the supportive network. In the case of Violetas, the learning process took place in a playful context, in which the players were able to analyze the knowledge acquired prior to the matches and the doubts that emerged from the questions composing the game.

It is a playful game, but it brings learning and has to make a positive reinforcement. If I couldn't learn or have positive reinforcement, it would be just a game, but it is much more than a game. You can incorporate that into your actions (...). Through the game, I thought we updated some things, for example, I searched about moral and sexual harassment (P22).

It should be noted that the playful context of the game is structured in scenes from movies that are presented in the introduction to the questions. For the participants, this was also associated with luck or bad luck in the cards withdrawal. It was observed that the movies scenes allowed the players to immerse in the different situations of violence experienced by the characters. The feeling of luck motivated participation 
and confidence in victory, while the perception of bad luck stimulated tension and the possibility of defeat.

We'll win! In fact, we all won. You can give it, we will win this card. Another good card for us! (P18).

But it's scary, it could be that card. Wait, because I'm still outraged due to the other mistake. Things got harder. Things got tough again $(\mathrm{P} 1)$.

The unpredictability of the game promoted fun and distraction for the players. However, it was found that as the pieces representing violence advanced through the cities on the board, the participants approached the concrete reality, breaking with the playful experience provided by the game.

\section{Limits of the Board Game Violetas to Face Violence Against Women}

At the beginning of the matches, the participants had to understand the components, rules and dynamics of the game. In spite of this, as they were not familiar to games, they believed that they would hardly be able to win. They also considered that the game can only be understood from the perspective of the involvement with the game.

I am not familiar with games, so at first I was concerned with the game, not with the theme. (...) I don't know anything about the game, so I figured: I don't know anything about games, I'm going to lose (P12).

The problem is that you only learn when you play (P14).

According to the participants, understanding the rules was cause for distress, as they believed it would be immediate, right at the start of the match. Only the reading of the rules was insufficient to master the dynamics of the components and the game was defined as complex.

When you started giving the rules, I found it a bit complicated, but it's like any game. Any game on the first play is a little complicated until you understand the interaction of the pieces, the dynamics, the objective, why it is there (P20).

The length of the questions was pointed out as a limiting factor for reading and interpretation. It was also associated with ambiguous responses, as they did not know whether they should be based on the fiction elicited by the game or on the concrete reality of professional practice.

We had doubts about some questions. There was one that we did not know if it was true or false (...). We had difficulty with some questions that seemed dubious, we read and said: but is it asking this? Does it want to know the positive side? The negative side? So maybe it was a difficulty in the interpretation of the question (P10).

With regard to the players' profiles, the participants stated that the game Violetas cannot be used with women in situations of violence, as they consider that these women do not have enough knowledge to answer the questions.
Reflections Stimulated by the Board Game Violetas for Professional Practice

It was found that participation in the game prompted the production and consolidation of knowledge to face violence against women. The game allowed the identification of visible and invisible interfaces of violence, which result in actions or omissions in professional practice. The difficulty in recognizing situations can be linked to sexist patterns, which produce and reproduce gender inequalities.

The game is an important work tool for men and women in an educational process on gender issues, understanding it as a relational issue, as it is not just women's problem (P23).

The match prompted discussions about the care provided by the professionals to the victimized women. The participants highlighted mainly the role of the social worker and health professionals in addressing the already established violence.

The healthcare professionals will assist, do what they have to do and do the referral (...). In fact, we have a practice that is not adequate, which is medicalization. That many professionals do not even ask why the woman shows this result. She has insomnia: go there and do the medicalization. But I think the right thing is for us to work on prevention. The ideal would be prevention, but what is practiced is medicalization (...). Nowadays, health problems due to violence are usually treated as a pathology (P10).

The workers associated the role of health services with care for physical problems, medicalization, and notification of cases of violence. They also commented on the lack of sensitivity, priority, embracement, and privacy in assisting users.

The game promoted considerations regarding the care provided by the players themselves. The transposition of the experiences lived in the professional practice to the board revealed feelings of insecurity, suffering, and insensitivity in the care to the users.

I thought that these little black pieces are things like this: you put a purple one and we have to surround the black one, it's like it was our pain, which we have to keep in our pockets to take care of other people's pain. Because every professional in the network has his/her problems and we cannot express them because we have to help (P24).

The participants also considered that regardless of the specialty of the service sector, it is necessary to provide embracement and qualified listening, since most users when seeking care are in a situation of vulnerability and feel very fragile.

The game allowed participants to recognize the importance of each specialty in assisting victimized women, as well as the establishment of interprofessional actions. Although each character in the game has the power to fight violence on the board, teamwork was responsible for ensuring the most effective intervention in solving the problems that arose in the game. 
Violence against women runs through collaboration, strategy, practicality, and team spirit, which were the powers here that our team used. I think coping is this: understanding what our powers are, our tools for acting (P27).

The different perspectives presented by the characters for the resolution of the problems contributed to the understanding of the phenomenon and the expansion of the alternatives of action. The participants noticed the importance of their work at the institution as part of the service offered to users.

In addition, they highlighted the relevance of understanding the dynamics of the social context, especially with regard to the mapping of services available in the territory and the configuration of the relationships established among them through the supportive network. They highlighted the differences among the existing networks in the capitals and in the inland cities, as well as the weaknesses due to the lack of participation and accountability of the professionals involved.

It is interesting that in the game you have all the partners present, so, within a network, this is essential for its functioning. When I think about this network issue and the networks that I have already participated in, I see this aspect as very fragile, because people are dispersed a lot. You need these people, in case the pieces are present in the decision-making process, in the planning of actions (...). The game makes us understand the importance of the participation of each member, really acting (...). People have not achieved this dimension yet. So, if there is so much talk about the network not working, this business will go nowhere, because I have no understanding of my political role in that network (P24).

The participants suggested the application of the game to all professionals involved in the coping network, so that they can experience collaborative work and reflect on the possibilities of intervention in the concrete reality.

\section{DISCUSSION}

The first contact with the board game Violetas caused the participants to feel insecure, because as adults, they revealed little familiarity with this type of educational strategy. However, it was found that this limitation was overcome through the collaborative strategy of the game. Thus, all players had the opportunity to share skills and knowledge to win the match.

The collaborative strategy of the game allowed sharing knowledge, experiences, and conceptions about gender issues and care for women in situations of violence. The playful context allowed the participants to establish a certain distance from their work object, allowing them to observe, compare, question and understand the aspects that make up violence against women.

The playful experience is related to what is not repeated and that can cause strangeness and contemplation. It involves the construction of bonds and the production of feelings based on the tension generated by chance, uncertainty and unpredictability ${ }^{(14)}$. The unpredictability is responsible for confirming the exceptionality of each move and the enchantment of the game. This way, the rules of daily life are temporarily suspended and the rules of the game are given meaning ${ }^{(15)}$.

The potentiality of the game for knowledge about a given theme was also evidenced in other studies, in which motivation was identified as an important element in the learning process, as the game has the ability to promote autonomy, dominance, and interaction among players ${ }^{(16-18)}$. The interaction benefits the understanding of the rules and the production of knowledge ${ }^{(19)}$. In addition, the game values the knowledge built by the players before the match ${ }^{(20)}$.

In this perspective, it is emphasized that the critical-emancipatory education has as premise the valorization of the students' socially constructed knowledge based on their community practice ${ }^{(21)}$. In the case of Violetas, the knowledge acquired during training and professional practice supported the answers to the questions that arose during the match.

The transposition of the experiences lived in the concrete reality to the board promoted the elaboration of the critic about the visibility of violence in public and private life, the assistance to women in situations of violence, carried out in an individual and interprofessional way, and the articulation of the supportive network in different geopolitical spaces. It was noticed that Violetas motivated the reflection on "the dynamic, dialectical movement, between doing and thinking about doing"(21).

The participants considered that the recognition of situations of violence implies professionals' action or inaction. They highlighted the importance of the embracement and qualified listening so that women can freely express their demands and feel supported to break the cycle of violations. They stressed the need for interprofessional care so that intervention measures can be expanded to overcome the problem. Based on the experience the match provided, in which all the actors were involved in preventing violence in the cities on the board, they highlighted the importance of strengthening the supportive network for the success of assistance to women.

During the matches, involvement of all participants was observed, as each player was responsible for the action of one of the characters. The interactions were established horizontally, so that there was an opportunity for listening and speaking. That way, the game proved to be a receptive space for doubts and concerns, in such a way that at times the discussions became so intense that the participants temporarily forgot that it was a game.

The participants also considered that Violetas allowed them to assess their own knowledge and practices. In addition, they were able to reflect collectively on the care offered to women at the CMB. It was found that, despite being inserted in the same institutional structure, the interaction established among the characters of the game was not noticed in the same way among professionals from different sectors of the CMB. This result evidenced the need to change the relationship established among professionals, 
so that actions to prevent and confront violence are in fact developed in an integrated manner.

At the end of the match, the participants recognized the game as an innovative experience in approaching the theme and suggested its application with the other professionals who work at $\mathrm{CMB}$, as well as in the other services that make up the supportive network in the city capitals where the study was conducted. Based on the experience with the game, some topics were also pointed out for the training of the team aiming at offering qualified and resolutive assistance.

On this basis, it is understood that participation in the game stimulated the search for new knowledge. Thus, it is considered that this educational strategy is not just an endpoint, but represents a means for learning about facing violence against women. Therefore, it is suggested that the use of the game be complemented with other educational activities in continuity with the questions and discussions raised in the game, seeking intervention measures in the concrete reality.

This result corroborates those from other studies that recognize the potentiality of the game to stimulate active participation, interaction and the learning process. However, they consider the game as a supplementary tool to the educational process ${ }^{(22)}$ or as a mediating tool for the establishment of dialogue, as the results depend on the players' intentionality ${ }^{(20)}$.

The present study had as a limitation the participation of professionals in only one match of the board game Violetas, which hindered the comprehension of the rules, the number of participants as the workshop took place concurrently with patient care, and the lack of health professionals. Although the health professional is one of the characters in the game, he/she is not part of the sectors that compose CMB. Thus, there is a need for similar workshops with the group of health workers.

These limitations are not thought to decrease the relevance of the study, as the results revealed Violetas as a powerful tool to stimulate reflections for the prevention and confrontation of violence against women among professionals from different areas who work in assisting the victims. Participation fostered the construction of new knowledge on the subject, the reinterpretation of personal and professional perceptions and concepts, in addition to the consolidation of learning generated during the match. It also stressed aspects in professional practice that need to be improved to overcome the problem.

\section{CONCLUSION}

Violetas is an educational strategy that can support the qualification of professionals to face violence against women. The participants considered the game attractive for the production of knowledge on the theme in a participatory manner. The learning process took place through the curiosity to know a technology based on the object of work, the valorization of the knowledge built before the match, the interaction through the respectful and horizontal dialogue, the autonomy for the individual and collaborative decision making, the motivation for critical reflection on professional practice, and the commitment of all players to win the match. Although games are considered an activity for younger generations, Violetas was well accepted among the participants, who reinforced the use with students and professionals who work in the supportive network or have some relationship with the theme.

\section{RESUMO}

Objetivo: Analisar as potencialidades e os limites do jogo Violetas para o enfrentamento da violência contra a mulher, na perspectiva dos profissionais que atuam no atendimento às vítimas. Método: Estudo interventivo de abordagem qualitativa. Participaram 30 profissionais das Casas da Mulher Brasileira de Brasília, Campo Grande e Curitiba. A coleta de dados foi realizada durante Oficinas de Trabalho Crítico-emancipatórias. Os dados foram submetidos à análise de conteúdo temática com o apoio do software webQDA. Resultados: Como potencialidades, os profissionais referiram o design do jogo, a participação colaborativa e a ludicidade como facilitadores do aprendizado, estimulando reflexões sobre a visibilidade da violência, a assistência às mulheres vitimadas e a articulação dos serviços da rede de enfrentamento. Como limitações, foram citados a falta de proximidade com jogos, o entendimento das regras e de algumas questões contidas no jogo. Conclusão: $\mathrm{O}$ jogo revelou-se como uma estratégia educativa potente para a formação e qualificação dos profissionais envolvidos na rede de enfrentamento.

\section{DESCRITORES}

Violência contra a Mulher; Jogos Experimentais; Gênero e Saúde; Cuidados de Enfermagem; Educação.

\section{RESUMEN}

Objetivo: Analizar las potencialidades y los límites del juego Violetas para el enfrentamiento de la violencia contra la mujer, en la perspectiva de los profesionales que actúan en el atendimiento a las víctimas. Método: Estudio de intervención con abordaje cualitativo. Participaron 30 profesionales de las Casas da Mulher Brasileira (Casas de la Mujer Brasileña) de Brasília, Campo Grande y Curitiba. La colecta de datos fue realizada durante Talleres de Trabajo Crítico-emancipatorios. Los datos fueron sometidos al análisis de contenido temático con el apoyo del software webQDA. Resultados: Como potencialidades, los profesionales refirieron el diseño del juego, la participación colaborativa y lo lúdico como facilitadores del aprendizaje, estimulando reflexiones acerca de la visibilidad de la violencia, la asistencia a las víctimas y la articulación de los servicios de la red de enfrentamiento. Se destacó como limitaciones: la falta de proximidad con juegos, la comprensión de las reglas y de algunas cuestiones referentes al juego. Conclusión: El juego demostró ser una estrategia educativa potente para la formación y cualificación de los profesionales comprometidos en la red de enfrentamiento.

\section{DESCRIPTORES}

Violencia contra la Mujer; Juegos Experimentales; Género y Salud; Atención de Enfermería; Educación. 


\section{REFERENCES}

1. United Nations. UN Women. Progress of the World's Women 2019-2020: families in a changing world [Internet]. New York: UN; 2019 [cited 2020 May 01]. Available from: https://reliefweb.int/sites/reliefweb.int/files/resources/Progress-of-the-worlds-women-2019-2020-en. pdf

2. United Nations; Department of Economic and Social Affairs. Transforming our world: the 2030 Agenda for Sustainable [Internet]. New York: UN; 2018 [cited 2020 May 01]. Available from: https://sustainabledevelopment.un.org/post2015/transformingourworld/publication

3. Semahegn A, Torpey K, Manu A, Assefa N, Tesfaye G, Ankomah A. Are interventions focused on gender-norms effective in preventing domestic violence against women in low and lower-middle income countries? A systematic review and meta-analysis. Reprod Health. 2019;16(1):93. https://doi.org/10.1186/s12978-019-0726-5

4. Doran F, Hutchinson M. Student nurses' knowledge and attitudes towards domestic violence: results of survey highlight need for continued attention to undergraduate curriculum. J Clin Nurs. 2017;26(15-16):2286-96. https://doi.org/10.1111/jocn.13325

5. Crombie N, Hooker L, Reisenhofer S. Nurse and midwifery education and intimate partner violence: a scoping review. J Clin Nurs. 2017;26(15-16):2100-25. https://doi.org/ 10.1111/jocn.13376

6. Pires MRGM, Almeida AN, Gottems LBD, Oliveira RNG, Fonseca RMGS. Gameplay, learning and emotions in the board game Violets: movie \& action in combating violence against women. Ciênc Saúde Coletiva. 2021;26(8):3277-88. DOI: https://doi.org/10.1590/141381232021268.00902020.

7. Brasil. Secretaria Especial de Políticas para as Mulheres. Casa da Mulher Brasileira. Programa mulher, viver sem violência: diretrizes gerais e protocolos de atendimento [Internet]. Brasília: SEPM; 2013 [cited 2020 maio 05]. Available from: http://www.spm.gov.br/assuntos/ violencia/programa-mulher-viver-sem-violencia

8. Minayo MCS. Amostragem e saturação em pesquisa qualitativa: consensos e controvérsias. Rev Pesq Qual [Internet]. 2017 [cited 2020 dez. 05];5(7):1-12. Available from: https://editora.sepq.org.br/rpq/article/view/82/59

9. Fonseca RMGS, Amaral MA. Reinterpretação da potencialidade das Oficinas de Trabalho Crítico-emancipatórias. Rev Bras Enferm. 2012;65(5):780-7. https://doi.org/10.1590/S0034-71672012000500010

10. Lourenço RG, Fonseca RMGS. Primary Health Care and the third sector in the face of violence between intimate adolescent partners. Rev Latino Am Enfermagem. 2020;28:e3341. http://dx.doi.org/10.1590/1518-8345.3811.3341

11. Bardin L. Análise de conteúdo. Lisboa: Edições 70; 2011.

12. Costa AP, Amado J. Content analysis supported by software. Aveiro: Ludomedia; 2018.

13. Brasil. Ministério da Saúde; Conselho Nacional de Saúde. Resolução no 466, de 12 de dezembro de 2012. Dispõe sobre diretrizes e normas regulamentadoras de pesquisas envolvendo seres humanos [Internet]. Brasília: CNS; 2012 [cited 2019 mar. 28]. Available from: http://bvsms.saude.gov.br/bvs/saudelegis/cns/2013/res0466_12_12_2012.html

14. Pires MRGM, Gottems LBD, Fonseca RMGS. Ludic reinvention in the development of games in health: theoretical-methodological frameworks for the production of critical subjectivities. Texto Contexto Enferm. 2017;26(4):e2500017. http://dx.doi.org/10.1590/010407072017002500017

15. Huizinga J. Homo Ludens: o jogo como elemento da cultura. 8a ed. São Paulo: Perspectiva; 2014.

16. Almeida LR, Machado LS, Medeiros AT, Coelho HFC, Andrade JM, Moraes RM. The caixa de Pandora game: changing behaviors and attitudes toward violence against women. Comput Entertain. 2018;16(3). https://doi.org/10.1145/3236493

17. Dalmina L, Barbosa JLV, Vianna HD. A systematic mapping study of gamification models oriented to motivational characteristics. Behav Inf Technol. 2019;38(11):1167-84. https://doi.org/10.1080/0144929X.2019.1576768

18. Noda S, Shirotsuki K, Nakao M. The effectiveness of intervention with board games: a systematic review. Biopsychosoc Med. $2019 ; 13: 22$. https://doi.org/10.1186/s13030-019-0164-1

19. van der Meij H, Veldkamp S, Leemkuil H. Effects of scripting on dialogues, motivation and learning outcomes in serious games. Br J Educ Technol. 2020;51(2):459-72. https://doi.org/ 10.1111/bjet.12851

20. Monteiro RJS, Oliveira MPCA, Belian RB, Lima LS de, Santiago ME, Gontijo DT. DECIDIX: meeting of the Paulo Freire pedagogy with the serious games in the field of health education with adolescents. Ciênc Saúde Coletiva. 2018;23(9):2951-62. https://doi.org/10.1590/141381232018239.12782018

21. Freire P. Pedagogia da autonomia. São Paulo: Paz e Terra; 2004.

22. Castro MJ, López M, Cao MJ, Castro MF, García S, Frutos M, et al. Impact of educational games on academic outcomes of students in the Degree in Nursing. PLoS One. 2019;14(7):e0220388. https://doi.org/10.1371/journal.pone.0220388

\section{Financial support}

Financial support from the São Paulo Research Foundation (FAPESP) - Process no. 2017/11960-6. Coordination for the Improvement of Higher Education Personnel (CAPES) - Finance Code 001. 